\title{
A Comparison of Pseudomonas solanacearum- resistant Tomato Cultivars as Hybrid Parents
}

\author{
William G. González \\ Estación Experimental Fabio Baudrit, Universidad de Costa Rica, Apdo. 183-4050, Alajuela, Costa Rica \\ William L. Summers ${ }^{2}$ \\ Department of Horticulture, Iowa State University, Ames, IA 50011-I 100
}

Additional index words. Lycopersicon esculentum, bacterial wilt, resistance, GCA, SCA, diallel

\begin{abstract}
Seven tomato Lycopersicon esculentum lines, 'Venus', 'Saturn', 'Rodade', 'Rotam 4', 'Hawaii 7998', 'UC-82B', and 'Stevens', and their 21 crosses were evaluated for their ability to resist infection by seven virulent strains of Pseudomonas solanacearum E.F. Sm. representing race 1 biovars 1 and 3. The Gardner and Eberhart model III analysis was used to evaluate the response of lines in crosses to $P$. solunaceurum infection. General combining ability mean squares were significant for all strains and in 5 of 7 instances specific combining ability mean squares were significant. In four instances the parent vs. cross contrast was significant. 'Hawaii 7998 ' was resistant to all seven strains of $P$. solanacearum, whereas 'Rotam 4' and 'Rodade' were resistant to biovar 3 and two races of biovar 1. 'Venus' and 'Saturn' were resistant to two other biovar 1 strains. 'Hawaii 7998' transmitted greater resistance than the other resistant parents, but its small fruit size and indeterminate growth habit make it a poor choice for a hybrid parent.
\end{abstract}

Tomato bacterial wilt (BW), caused by the soilborne bacterium Pseudomonas solanacearum is a widely distributed disease in tropical, subtropical, and some warm temperate regions of the world with a host range of 44 plant families (Hayward, 1991). Strains of $P$. solanacearum differ in host range, geographical distribution, pathogenicity,epidemiologicalrelationship, andphysiological properties (Buddenhagen and Kelman, 1964; Cook et al., 1989; Kelman, 1953; Palleroni and Doudoroff, 1971). Some pathogen strains are particularly noted for the tremendous losses inflicted on some members of the Solanaceae grown in warm, humid areas (Acosta et al., 1964).

In tomato, interest in host-plant resistance to bacterial wilt has been emphasized by the inability to control the disease through field rotation or soil fumigation and by the publics demand for reduced pesticide use (Acosta et al., 1964). Although some tomato cultivars have been developed with adequate levels of resistance to specific BW strains in certain environments, cultivars with stable resistance to BW strains found under conditions of high temperature and humidity in the lowland tropics are difficult to obtain (Bosch et al., 1990; De Leon, 1987; Henderson and Jenkins, 1977; Kelman, 1953; Lasso, 1974; Mew and Ho, 1977; Peterson et al., 1983). Development of commercial BW resistant tomatoes with acceptable fruit size and quality has been difficult. McGuire (1960) encountered considerable difficulty in combining commercial fruit size and good horticultural characteristics with optimum levels of resistance in progeny derived from crosses between root knot nematode resistant Hawaiian lines and BW-tolerant North Carolina lines. Part of the reason for this difficulty may be the polygenic control of resistance reported by Singh (1961). In contrast, Acosta (1964) found that resistance was controlled in a partly dominant fashion when resistant germplasm derived from Lycopersicon pimpinellifolium, PI 127805A was used.

Received for publication 18 Nov. 1994. Accepted for publication 17 Apr. 1995. Journal Paper No. J-16010 of the Iowa Agriculture and Home Economics Experiment Station, Ames, Iowa. Project 3123. Research taken from a thesis by William González in partial fulfillment of the requirements for the MS in horticulture. The cost of publishing this paper was defrayed in part by the payment of page charges. Under postal regulations, this paper therefore must be hereby marked advertisement solely to indicate this fact.

${ }^{1}$ Graduate student.

${ }^{2}$ Associate professor.
Studies conducted at the Asian Vegetable Research and Development Center (AVRDC, Taiwan) suggest that resistance to BW may be controlled by multiple genes acting additively (AVRDC, 1974). By use of another source of resistance to bacterial wilt, PI 126408-6-BK, Ferrer (1974) determined that resistance was polygenically controlled and not linked with small fruit size. Sonada and Augustine (1978) reported that PI 126408-6-BK was highly resistant to BW under field conditions in Florida.

Louw (198 1) studied the inheritance of BW resistance derived from the North Carolina line BW2, using a South African $P$. solanacearum strain. His data fit a two- gene model (A and B) with epistasis. Gene A was epistatic over gene B, and gene B did not contribute to bacterial wilt resistance in the absence of $\mathrm{A}$. He also reported that genes $\mathrm{A}$ and $\mathrm{B}$ are dominant with incomplete penetrance and suggested that line BW2 was probably the source of gene A and 'Roma VF' the source of gene B.

There is general agreement that more than one gene controls resistance to BW. Few studies, however, have estimated the combining ability of tomato cultivars when scored for BW resistance, even though field observations suggest that some lines transmit their resistance more effectively than others. Such lines possess greater potential to be used as parents in breeding programs (AVRDC, 1983).

In this study, the specific objectives were a) to determine the most resistant tomato cultivars to seven $P$. solanacearum strains; b) to compare combining abilities of the seven tomato cultivars when each was used as a tester to establish the best parental combiners; and c) to identify either the more resistant $\mathrm{F}_{1} \mathrm{~s}$ for use as hybrid varieties, or to produce $\mathrm{F}_{2}$ populations for the breeding and selection.

\section{Materials and Methods}

Plant materials chosen as parents for this study were five BW resistant tomato cultivars, 'Venus', 'Saturn', 'Rodade', 'Rotam 4', and 'Hawaii 7998', and two BW susceptible cultivars, 'UC-82B' and 'Stevens', which have potential to be used under conditions of high temperature and humidity in the lowland tropics (Table 1). Seven experiments were conducted, one per each BW strain, in which plots representing the seven parents and their 21 crosses were assigned to a randomized complete block design with four 
Table 1. Cultivars used as parents in the diallel analysis of tomato host-plant resistance to Pseudomonas solanacearum (biovars 1 and 3 ).

\begin{tabular}{|c|c|c|c|c|}
\hline Cultivar & Origin & Type $^{2}$ & $\begin{array}{l}\text { Plant } \\
\text { habit }^{y}\end{array}$ & $\begin{array}{c}\text { Source of } \\
\text { BW resistance }\end{array}$ \\
\hline UC-82B & $\mathrm{AES}^{\mathrm{x}}$, Univ. of Calif. & $\mathrm{P}$ & $\mathrm{D}$ & -- \\
\hline Stevens & $\begin{array}{l}\text { Vegetable and Ornamental } \\
\text { Plant Res. Inst., South Africa }\end{array}$ & FM & $\mathrm{D}$ & - \\
\hline Venus & AES, NC. State Univ. & FM & I & $\begin{array}{c}\text { Beltsville no. } 3841 \\
\text { and PI } 129080\end{array}$ \\
\hline Saturn & AES, N.C. State Univ. & FM & I & $\begin{array}{l}\text { Beltsville no. } 3841 \\
\text { and PI } 129080\end{array}$ \\
\hline Rodade & Hort. Res. Inst., South Africa & FM & $\mathrm{D}$ & $\begin{array}{l}\text { Line BW-2 } \\
\text { N.C. }\end{array}$ \\
\hline Rotam 4 & $\begin{array}{l}\text { Vegetable and Ornamental } \\
\text { Plant Res. Inst., South Africa }\end{array}$ & FM & $\mathrm{D}$ & $\begin{array}{l}\text { Line BW-4 } \\
\text { N.C. }\end{array}$ \\
\hline Hawaii 7998 & AES, Univ. of Hawaii & $\mathrm{L}$ & I & PI $127805 \mathrm{~A}$ \\
\hline
\end{tabular}

${ }^{\overline{\mathrm{P}}} \mathrm{P}=$ Processing tomato; $\mathrm{FM}=$ fresh market tomato; $\mathrm{L}=$ breeding line.

${ }^{\mathrm{y}} \mathrm{D}=$ determinate; $\mathrm{I}=$ indeterminate.

${ }^{\mathrm{x}} \mathrm{AES}=$ Agricultural Experiment Station.

replications. Two rows of seeds per entry were seeded into soil media, $\mathrm{pH} 5.5$, (50\% peatmoss, $30 \%$ perlite and $20 \%$ soil), which had been sieved through a $6 \mathrm{~mm}^{2}$ mesh screen and steam-pasteurized. Seeds were sown $2.4 \mathrm{~cm}$ apart in HD 20-row seed flats (Jiffy; A. H. Hummert Seed Co., St. Louis). This flat was chosen to reduce interplot interference because each row within the flat was separated by a plastic ridge. After the seeds were sown, a thin layer of coarse vermiculite was placed on top to retain soil moisture. Flats were placed in a greenhouse held at a constant temperature of $25 \mathrm{C}$ $\pm 3 \mathrm{C}$ and watered daily. After 10 days, seedlings were thinned to 11 per row. Watering was suspended $36 \mathrm{~h}$ before inoculation and was resumed $24 \mathrm{~h}$ after inoculation. A 14-h photoperiod was provided for the duration of each experiment.

Seven strains of P. solanacearum, UW-25, UW-258, UW-256, UW-275 (race 1, biovar 1), UW-255, UW-130, and UW-8 (race 1, biovar 3), virulent on tomato, were used in this study. These strains were obtained from the collection held at the Dept. of Plant Pathology, Univ. of Wis. (UW), Madison. Each strain has been characterized using DNA probes and RFLP analysis, in addition to the race and biovar grouping (Cook et al., 1989; Cook et al., 1990).

To prepare the inoculum, stock cultures stored in sterile Type I water were streaked on Kelman's tetrazolium chloride medium, TZC-agar (Kelman, 1954), and incubated for $48 \mathrm{~h}$ at 30C. Fluidal, wild-type colonies were selected and restreaked on the same medium without TZC (Bacto-agar). After $48 \mathrm{~h}$ of incubation at $30 \mathrm{C}$, colonies were harvested in sterile $0.1 \mathrm{~m}$ phosphate buffer, $\mathrm{pH}$ 7.2, and washed twice. Bacterial cells were recovered after each cycle by centrifuging at $6000 \times \mathrm{g}$ for $10 \mathrm{~min}$ at room temperature. After the last wash, the bacterial cell pellet was resuspended in sterile distilled water and the suspension diluted to $10^{8}$ colonyforming units per milliliter ( $\mathrm{cfu} / \mathrm{ml})$, which was determined spectrophotometrically by comparing absorbance at $600 \mathrm{~nm}$ with a previously constructed standard curve.

Plants (21 days old) were screened for disease resistance. At this stage of growth the seedlings possessed two true leaves and were approximately 10 to $15 \mathrm{~cm}$ tall. Fifty milliliters of the inoculum were added at the base of the seedlings in each row of the flat (ratio of inoculum to soil volume was 1:3 respectively; 1 liter/flat). Roots were immediately cut by running a sharp knife in the planting medium between and across the rows of seedlings (Gonzalez et al., 1973). After inoculation, flats were maintained in a greenhouse at a constant air temperature of $28 \pm 3 \mathrm{C}$ and $26 \pm 2 \mathrm{C}$ soil temperature.
Ratings for BW interaction phenotypes (IP) were determined 20 days post inoculation on a 0 (best) to 9 ( worst) scale of increasing disease severity, using a modification of Williams' (1988) scaling for the nonmetric quantification of the IP. Disease scores were described as: $0=$ no interaction phenotype (immunity), 1 = no wilt symptoms, but foliar yellowing and growth reduction as compared with a non-inoculated control, $3=$ one or two leaves partially wilted or dead, $5=$ all leaves, except the meristem wilted, $7=$ all leaves and the meristem wilted, but at least $50 \%$ of the stem erect and turgid, and $9=$ dead plant. A disease index (DI) was calculated as the number of plants in an entry with a particular rating, multiplied by that rating. Within an entry, all indices were summed and then divided by the total number of plants in that entry. The DI served as a measure of central tendency or weighted mean (Steel and Torrie, 1980):

$\mathrm{DI}=\overline{\mathrm{Y}}=\Sigma \mathrm{f}_{\mathrm{i}} \mathrm{Y} / \boldsymbol{\Sigma} \mathbf{f}_{\mathrm{i}}$

where $f_{i}=$ the frequency of plants possessing a particular disease score, and $\mathrm{Y}_{\mathrm{i}}=$ disease score.

An analysis of variance for resistance to $\mathbf{P}$. solanacearum was accomplished by using the model for a randomized complete block design for each strain studied. The model assumed that genotypes (parents and their 21 crosses) were fixed effects, and replications were random effects (Model I). Gardner and Eberhart's (1966) Analysis III for a set of parents (p) and their $[\mathrm{p}(\mathrm{p}-1)] / 2$ single crosses was used to determine general (GCA) and specific (SCA) combining ability effects. Combining ability effects were estimated using multiple linear regression (Steel and Torrie, 1980). GCA effects were used to measure the average performance of the parents in hybrid combination, whereas SCA effects determine those instances in which the performance of the hybrids was either better or worse than would be expected on the basis of the performance of the parents involved (Sprague and Tatum, 1942). Gardner and Eberhart's (1966) Analysis III, estimates GCA effects for each parent from progeny data only. For this reason, standard errors for effects and the differences between effects were computed by using the formulae provided by Griffing (1956) for experimental method 4, Model I.

\section{Results and Discussion}

Significant differences were observed among cultivars and crosses for the four $\mathbf{P}$. solanacearum strains assigned to biovar 1 
and the three strains assigned to biovar 3 (Table 2). There were no significant differences for the interaction of parents vs. crosses for strains UW-25 and UW-256 (race 1, biovar 1). Significant differences were observed for GCA but not for SCA in the evaluations with strains UW-25 and UW-256 (Table 2). GCA and SCA are often used as estimates of additive and nonadditive effects, respectively. Additionally, the mean square for parents vs. crosses reflects average heterosis, which is in part attributable to nonadditive genetic effects (Gardner and Eberhart, 1966). The significant GCA and the nonsignificant SCA and parents vs. crosses suggests the predominance of additive gene action in determining the expression of resistance to $P$. solanacearum strains UW-25 and UW-256 in the tomato cultivars evaluated.

Significant differences were found among parents, parents vs. crosses, crosses, GCA and SCA for experiments in which strains UW-258, UW-275, UW-130, and UW-8 were used (Table 2). The significance of the contrast, parents vs. crosses (average heterosis test), and SCA suggested the presence of nonadditive genetic effects within F, crosses (Sokol and Baker, 1977). The contrast parents vs. crosses was not significant for strain UW-255. However, highly significant SCA effects indicate that nonadditive genetic effectsalso contribute to the expression of resistance to $\mathbf{P}$. solanacearum strain UW-255. Sprague and Tatum (1942) and Bhullar et al. (1979) have pointed out that a large GCA and small SCA values suggest the predominance of additive gene effects.

Significant GCA mean squares and GCA mean squares considerably larger than SCA mean squares were observed for all diallel analyses (Table 2). This finding suggests that the additive genetic effects of the seven parents used are more important than the nonadditive effects in determining BW resistance. Recurrent selection would be appropriate to accumulate genes for resistance to the seven P. solanacearum strains we evaluated. Simultaneously, other breeding methods, such as pedigree or single seed descendant, could be used to develop and select lines resistant to BW.

A summary of disease index values for each tomato line and $\mathbf{P}$. solanacearum strain evaluated is presented in Table 3. Greater levels of resistance to biovar 1 and 3 strains were noted in 'Hawaii 7998' and the South African materials 'Rotam 4', and 'Rodade'. North Carolina cultivars, 'Saturn' and 'Venus', exhibited resistance to selected biovar 1 strains, but they were susceptible to UW25 and three biovar 3 strains. Similarly, 'UC-82B' expressed some resistance to UW-258. Statistical differences for resistance (DI) were observed between 'Hawaii 7998' and 'Rotam 4' for strain UW-25. 'Rotam 4' exhibited better resistance than 'Rodade' for the $P$. solanacearum strains UW-25, UW-258, UW-256, and UW255. The most resistant commercial phenotype/DI combinations are 'Rotam 4' x 'Venus' and 'Rodade' x 'Rotam 4' for fresh market lines and 'Rotam 4' $\mathrm{x}$ 'UC-82B' for processing.

GCA effects are presented in Table 4 . The best parents would be those that exhibit more negative (resistant) GCA effects (Baker, 1978) and good horticultural characteristics (Fehr, 1987). Using these principles of selection the more promising parents in this study would be 'Rotam 4', 'Venus' and 'Saturn'. Because 'Venus' and 'Saturn' possess similar pedigrees (Henderson and Jenkins, 1977), the crosses 'Rotam 4' x 'Venus', and 'Rotam 4' x 'Saturn' are expected to produce the more horticulturally adapted, BW resistant progeny in the least amount of time. In diallel analyses conducted for the AVRDC in Taiwan (AVRDC, 1983), the cultivar 'Saturn' was reported to be a better source of BW resistance than L-336 and L-4670, currently used as resistant parents in the AVRDC breeding program. The cultivar 'Hawaii 7998' also produced negative GCA effect values for resistance to all of the $\boldsymbol{P}$. solanacearum strains evaluated, but we observed that crosses with 'Hawaii 7998' contain some undesirable characteristics. Fruit size was small, $53 \mathrm{~g}$ on average, for crosses between 'Hawaii 7998' and the fresh-market cultivars, and fruit size was even smaller, $38 \mathrm{~g}$, for the cross to the processing type, 'UC-82B'. Crosses containing 'Hawaii 7998' as one parent also exhibited an indeterminate growth habit and profuse branching.

SCA effects suggest that 13 of the $21 \mathrm{~F}$, hybrids exhibited negative (resistant) SCA effects to two or more BW strains (Table 4). 'Rotam 4' x 'UC-82B', 'Rotam 4' x 'Stevens', 'Rotam 4' x 'Venus', 'Rotam 4' x 'Saturn', 'Rodade' x 'Venus', and 'Rodade' $\mathrm{x}$ 'Saturn' showed negative SCA effects for most of the seven $\mathbf{P}$. solanacearum strains. Progeny may be advanced to further generations with the intent of selecting promising genotypes within segregating populations. Some of the hybrids with 'Hawaii 7998' also presented negative SCA effects for several P. solanacearum strains. However, considerable backcrossing and selection will be required to obtain suitable commercial phenotypes.

There is close agreement between parental BW resistance (DI) and their GCA for resistance. Cultivars with greater levels of resistance to bacterial wilt generally produce offspring with better levels of BW resistance. However, 'Hawaii 7998' x 'Rodade', 'Hawaii 7998' x 'Rotam 4', 'Rodade' x 'Rotam 4', and 'Venus' x 'Saturn' did not produce acceptable SCA values for most of the $\mathbf{P}$. solanacearum strains evaluated. 'Rotam 4' and 'Rodade', as well as 'Saturn' and 'Venus' are related (Bosch et al., 1985; Bosch et al.,

Table 2. Analysis of variance for host-plant resistance to Pseudomonas solanacearum, strains UW-25, UW-258, UW-256, and UW-275 (race 1, biovar 1) and strains UW-255, UW-130, and UW-8 (race 1, biovar 3) in seven tomato cultivars and one set of their 21 possible single crosses.

\begin{tabular}{lrccccccc}
\hline \hline & \multicolumn{7}{c}{ Mean Square } \\
\cline { 2 - 8 } Source of & & Strain & Strain & Strain & Strain & Strain & Strain & Strain \\
variation & df & UW-25 & UW-258 & UW-256 & UW-275 & UW-255 & UW-130 & UW-8 \\
\hline Replication & 3 & $28.13^{* * *}$ & $7.68^{* * *}$ & $31.54^{* * *}$ & $2.74^{\text {NS }}$ & $47.76^{* * *}$ & $7.98^{* * *}$ & $48.14^{* * *}$ \\
Entries & 27 & $4.46^{* * *}$ & $8.60^{* * *}$ & $10.82^{* * *}$ & $32.44^{* * *}$ & $20.31^{* * *}$ & $37.12^{* * *}$ & $30.30^{* * *}$ \\
Parents (P) & 6 & $6.49^{* * *}$ & $15.39^{* * *}$ & $16.55^{* * *}$ & $39.21^{* * *}$ & $35.23^{* * *}$ & $50.51^{* * *}$ & $37.97^{* * *}$ \\
P vs. C & 1 & $1.35^{\text {NS }}$ & $16.49^{* * *}$ & $5.62^{\text {NS }}$ & $46.16^{* * *}$ & $1.01^{\text {NS }}$ & $39.40^{* * *}$ & $24.95^{* * *}$ \\
Crosses (C) & 20 & $4.01^{* * *}$ & $6.17^{* * *}$ & $9.36^{* * *}$ & $29.72^{* * *}$ & $16.80^{* * *}$ & $32.99^{* * *}$ & $28.26^{* * *}$ \\
GCA $^{2}$ & 6 & $11.36^{* * *}$ & $12.35^{* * *}$ & $27.04^{* * *}$ & $82.49^{* * *}$ & $42.94^{* * *}$ & $92.37^{* * *}$ & $81.49^{* * *}$ \\
SCA & 14 & $0.86^{\text {NS }}$ & $3.52^{* * *}$ & $1.78^{\text {NS }}$ & $7.11^{* * *}$ & $5.60^{* *}$ & $7.54^{* * *}$ & $5.45^{* * *}$ \\
Error & 81 & 1.02 & 0.57 & 1.49 & 1.99 & 2.08 & 1.19 & 1.30 \\
CV $(\%)$ & & 14.02 & 28.27 & 20.97 & 30.71 & 22.52 & 21.49 & 20.47
\end{tabular}

${ }^{2} \mathrm{GCA}$ and SCA refer to general and specific combining ability, respectively.

Ns, $* *, * * *$ Nonsignificant or significant at $\mathrm{P}=0.01$ or 0.001 , respectively. 
Table 3.Mean disease index for host-plant resistance to Pseudomonas solanacearum strains UW-25, UW-258, UW-256, UW-275 (race 1, biovar 1), UW-255, UW-130, and UW-8 (race 1, biovar 3) estimated for seven tomato cultivars and one set of their 21 possible single crosses.

\begin{tabular}{|c|c|c|c|c|c|c|c|}
\hline \multirow[b]{2}{*}{ Parent or $\mathrm{x}$} & \multicolumn{4}{|c|}{ Biovar $1^{2}$} & \multicolumn{3}{|c|}{ Biovar 3} \\
\hline & $U W-25^{y}$ & UW-258 & UW-256 & UW-275 & UW-255 & UW-130 & UW-8 \\
\hline UC-82B & 6.7 & 3.7 & 8.1 & 8.6 & 8.4 & 8.9 & 9.0 \\
\hline Stevens & 8.6 & 7.1 & 8.5 & 9.0 & 9.0 & 9.0 & 9.0 \\
\hline Venus & 8.1 & 2.2 & 5.1 & 6.2 & 8.9 & 8.9 & 8.7 \\
\hline Saturn & 8.1 & 2.1 & 5.4 & 8.5 & 9.0 & 9.0 & 8.6 \\
\hline Rodade & 8.5 & 4.6 & 8.2 & 3.2 & 5.3 & 2.8 & 4.1 \\
\hline Rotam 4 & 6.9 & 1.6 & 4.5 & 1.5 & 2.5 & 2.1 & 2.8 \\
\hline Hawaii 7998 & 5.0 & 2.1 & 3.6 & 2.9 & 2.9 & 2.1 & 2.5 \\
\hline UC-82B x Stevens & 8.2 & 6.0 & 8.4 & 8.8 & 9.0 & 8.5 & 9.0 \\
\hline UC-82B x Venus & 6.6 & 2.0 & 5.5 & 8.1 & 9.0 & 8.9 & 8.8 \\
\hline UC-82B x Saturn & 6.2 & 1.8 & 5.4 & 7.4 & 9.0 & 8.7 & 8.9 \\
\hline UC-82B x Rodade & 8.0 & 4.1 & 8.1 & 3.8 & 7.6 & 5.7 & 7.2 \\
\hline UC-82B x Rotam 4 & 7.6 & 1.8 & 6.3 & 3.3 & 5.5 & 5.1 & 5.3 \\
\hline UC-82B x Hawaii 7998 & 7.2 & 2.0 & 5.1 & 2.7 & 6.8 & 4.4 & 4.1 \\
\hline Stevens $\mathrm{x}$ Venus & 7.9 & 2.1 & 5.0 & 8.0 & 9.0 & 9.0 & 8.8 \\
\hline Stevens x Saturn & 8.2 & 2.2 & 7.0 & 8.5 & 9.0 & 9.0 & 8.9 \\
\hline Stevens x Rodade & 8.8 & 5.7 & 7.5 & 4.1 & 6.5 & 4.3 & 6.3 \\
\hline Stevens $\mathrm{X}$ Rotam 4 & 8.2 & 2.1 & 7.8 & 3.8 & 6.5 & 3.7 & 4.9 \\
\hline Stevens x Hawaii 7998 & 7.2 & 2.6 & 6.2 & 2.3 & 5.9 & 2.5 & 3.8 \\
\hline Venus x Saturn & 6.8 & 2.1 & 4.8 & 8.7 & 9.0 & 9.0 & 9.0 \\
\hline Venus $\mathrm{x}$ Rodade & 7.3 & 2.3 & 5.8 & 2.3 & 4.9 & 2.8 & 3.2 \\
\hline Venus $\mathrm{x}$ Rotam 4 & 7.3 & 1.5 & 3.9 & 1.9 & 4.3 & 2.3 & 2.5 \\
\hline Venus x Hawaii 7998 & 5.1 & 1.7 & 2.9 & 1.6 & 3.4 & 1.9 & 2.6 \\
\hline Saturn x Rodade & 7.3 & 2.2 & 5.1 & 2.8 & 6.2 & 2.7 & 4.2 \\
\hline Saturn x Rotam 4 & 6.8 & 2.1 & 6.0 & 3.6 & 5.1 & 3.3 & 3.5 \\
\hline Saturn x Hawaii 7998 & 5.1 & 1.7 & 2.9 & 2.2 & 3.4 & 2.2 & 2.9 \\
\hline Rodade x Rotam 4 & 7.9 & 1.7 & 6.4 & 1.7 & 4.1 & 1.7 & 2.6 \\
\hline Rodade x Hawaii 7998 & 6.9 & 2.3 & 5.2 & 1.6 & 3.5 & 2.1 & 2.9 \\
\hline SE & 0.7 & 0.5 & 0.8 & 1.0 & 1.0 & 0.8 & 0.8 \\
\hline $\mathrm{LSD}=0.05^{\mathrm{x}}$ & 1.4 & 1.1 & 1.7 & 1.9 & 2.0 & 1.5 & 1.6 \\
\hline
\end{tabular}

${ }^{2}$ Disease index. Resistant classes based on disease index (DI): very resistant $=$ DI of 0 to 3 , moderately resistant $=$ DI of 3.1 to 5 , slightly resistant $=$ DI of 5.1 to 6 , susceptible $=$ DI of 6.1 to 7 , and very susceptible $=$ DI of 7.1 to 9 . Data are means of four replications.

${ }^{y}$ Different statistical analyses were used for each BW strain. Direct statistical comparisons among mean DI for different strains is not possible. ¿LSD for comparisons among parent means, among means of crosses with different parents, and means of crosses with a common parent for each BW strain.

1990; Henderson and Jenkins, 1977). It is possible that 'Saturn' and 'Venus' share similar genes for BW resistance, and for this reason did not perform as well as expected.

This study has demonstrated that the seven parents and their crosses showed significant differences in both GCA and SCA for resistance to BW. Moreover, different effects were observed within the diallel analysis between the two $P$. solanacearum biovar's, and between the strains of each biovar. Such differences emphasize the need to evaluate resistant lines and local BW strains before selecting a crossing and selection scheme for a new breeding program.

\section{Literature Cited}

Acosta, J.C., J.C. Gilbert, and V.L. Quinon. 1964. Heritability of bacterial wilt resistance in tomato. Proc. Amer. Soc. Hort. Sci. 84:455-462.

AVRDC. 1974. Annual report for 1972-1973. Asian Vegetable Research and Development Center, Tainan, Taiwan, Republic of China.

AVRDC. 1983. Evaluation of bacterial wilt resistant stocks as parents. 1983

Progress Report. Asian Veg. Res. and Dev. Ctr, Tainan, Taiwan, Republic of China.

Baker, R.J. 1978. Issues in diallel analysis. Crop Sci. 18:553-536.

Bhullar, G.S., K.S. Gill, and A.S. Khehra. 1979. Combining ability analysis over $\mathrm{F}_{1}-\mathrm{F}_{5}$ generations in diallel crosses of bread wheat. Theoretical Applied Genet. 55:77-80.

Bosch, S.E., A.J. Louw, and E. Aucamp. 1985. 'Rodade' bacterial resistant tomato.
HortScience 20:458-459.

Bosch, S.E., B.H. Boelena, J.J. Serfontein, and A.E. Swaneopoel. 1990. 'Rotam 4'. a multiple disease resistant fresh-market tomato. HortScience 20:458-459.

Buddenhagen, I.W. and A. Kelman. 1964. Biological and physiological aspects of bacterial wilt caused by Pseudomonas solanacearum. Annu. Rev. Phytopathol. 2:203-230.

Cook, D., E. Barlow, and L. Sequeira. 1989. Genetic diversity of Pseudomonas solanacearum: detection of restriction fragment length polymorphisms with DNA probes that specify virulence and the hypersensitive response. Mol. PlantMicrobe Interactions 2(3):113-121.

Cook, D., E. Barlow, and L. Sequeira. 1990. DNA probes as tools for the study of host-pathogen evolution: the example of Pseudomonas solanacearum, p. 103108. In: H. Hennecke and D.P. Verna (eds.). Advances in molecular genetics of plant-microbe interactions. Proc. 5th Intl. Symp. Mol. Gene. Plant-Microbe Interactions. Kluwer, London.

De Leon, G. 1987. Proceso para la obtención de resistencia de tomate a Pseudomonas solanacearam en Panama Manejo Integrado de Plagas 5:11-15.

Fehr, W.R. 1987. Principles of cultivar development. McGraw-Hill, New York.

Ferrer Z., A. 1974. Resistance to Pseudomonas solanacearum in Lycopersicon esculentum. PhD thesis. Univ. of Florida.

Gardner, C.O. and S.A. Eberhart. 1966. Analysis and interpretation of the variety cross diallel and related populations. Biometrics 22:439-452.

Gonzalez, L.C., L. Sequeira, and P.R. Rowe. 1973. A root inoculation technique to screen potato seedlings for resistance to Pseudomonas solanacearum. Amer. Potato J. 50(3):96-104.

Griffing, B. 1956. Concept of general and specific combining ability in relation to 
Table 4. Estimates of general and specific combining ability effects for host-plant resistance to Pseudomonas solanacearum strains UW-25, UW-258, UW-256, UW-275 (race 1, biovar 1), and UW-255, UW-130, UW-8 (race 1, biovar 3), based on the mean performance of F, hybrids.

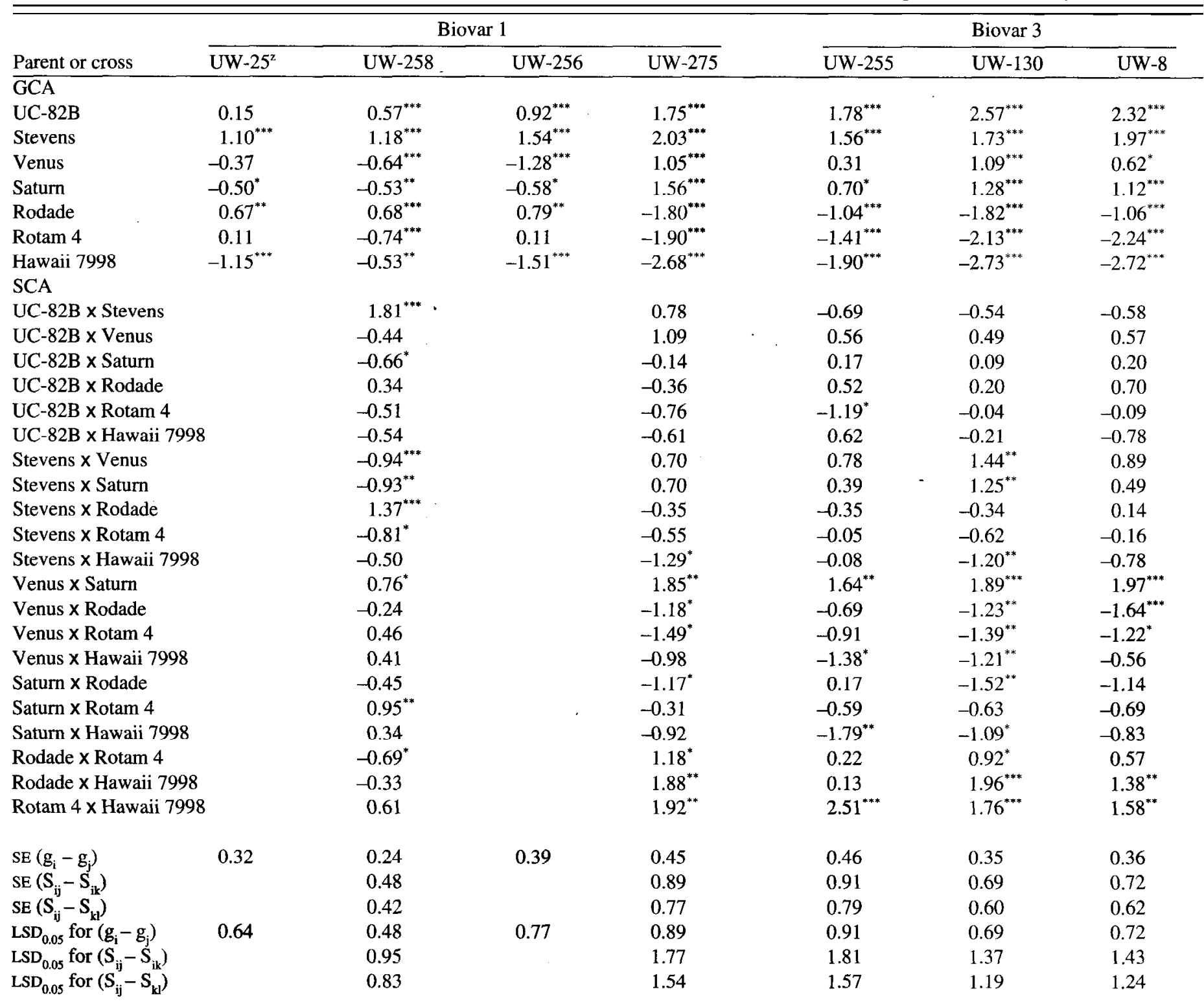

$\overline{{ }^{2}}$ Different statistical analyses were used for each BW strain. Direct statistical comparisons among GCA or SCA estimates for different strains are not possible.

$*, * * * * *$ Significantly different from zero at $\mathrm{P}=0.05,0.01$, or 0.001 , respectively.

diallel crossing systems. Austral. J. Biol. Sci. 9:463-493.

Hayward, A.C. 1991. Biology and epidemiology of bacterial wilt caused by Pseudomonas solanacearum. Annu. Rev. Phytopathol. 29:65-87.

Henderson, W.R. and SF. Jenkins. 1977. Venus and Saturn: Two new tomato varieties combining desirable horticultural features with southern bacterial wilt resistance. NC. Agr. Expt. Sta. Res. Bul. 444.

Kelman, A. 1953. The bacterial wilt caused by Pseudomonas solanacearum. N.C. Agr. Expt. Sta. Tech. Bul. 99.

Kelman, A. 1954, The relationship of pathogenicity in Pseudomonas solanacearum to colony appearance on tetrazolium medium. Phytopathol. 44:693-695.

Lasso, R. 1974. Desarrollo de variedades de tomate industrial tolerantes a Pseudomonas solanacearum mediante cruza interespecífica. Fitotec. Latinoam. (Ven.) $10(1): 36-51$

Louw, A.J. 1981. Teling vir weerstand teen bakteriese verwelksiekte by tamaties. $\mathrm{PhD}$ thesis. Univ. of Pretoria, South Africa.

McGuire, DC. 1960. Bacterial wilt resistant tomatoes. Hawaii Agr. Expt. Sta. Biennial Rpt. 1958-1960.

Mew, T.W. and W.C. Ho. 1977. Effect of soil temperature on resistance of tomato cultivars to bacterial wilt. Phytopathol. 67:909-911.
Palleroni, N.J. and M. Doudoroff. 1971. Phenotypic characterization and deoxyribonucleic acid homologies of Pseudomonas solanacearum. J. Bacterial. 107:690696.

Peterson, R.A., A.J. Inch, M.E. Herrington, and J. Saranah. 1983. Scorpio: a tomato resistant to bacterial wilt biovar 3. Austral. Plant Pathol. 12:8-10.

Singh, K. 1961. Inheritance of North Carolina type of bacterial wilt resistance in tomato, Lycopersicon esculentum L. MS thesis. Univ. of Hawaii.

Sokol, M.J. and R.J. Baker. 1977. Evaluation of the assumptions required for the genetic interpretation of diallel experiments in self-pollinating crops. Can. J. Plant Sci. 57:1185-1191.

Sonada, R.M. and J. Augustine. 1978. Reaction of bacterial wilt-resistant tomato lines to Pseudomonas solanaceurum in Florida. Plant Dis. Rpt. 62(5):464-446. Sprague G.F. and L.A. Tatum. 1942. General and Specific combining ability in single crosses of corn. J. Amer. Soc. Agr. 34:923-932.

Steel, R.G.D. and J.H. Torrie. 1980. Principles and procedures of statistics. A biometrical approach. 2nd ed. McGraw-Hill, New York.

Williams, P.H. 1988. Screening for resistance to diseases, p. 336362. In: A.H.D. Brown, O.H. Frankel, D.R. Marshall, and J.T. Williams (eds.). The use of plant genetic resources. Cambridge Univ. Press, New York. 